\title{
Indvielse af Geologisk Institut - kunsten stiger
}

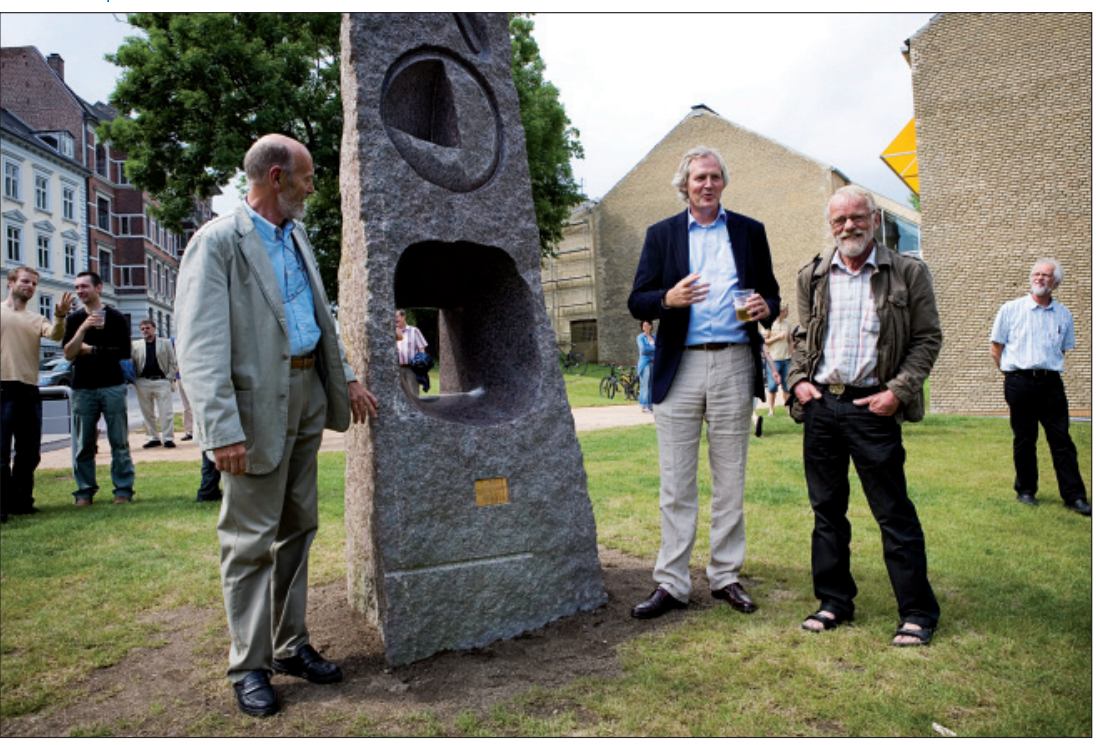

John Korstgård (tv.), Brian Jepsen, Altinex AS (midtfor) og Magnus Krogh Andersen (th.) ved skulpturen. (Foto: Søren S. Kjeldgaard)

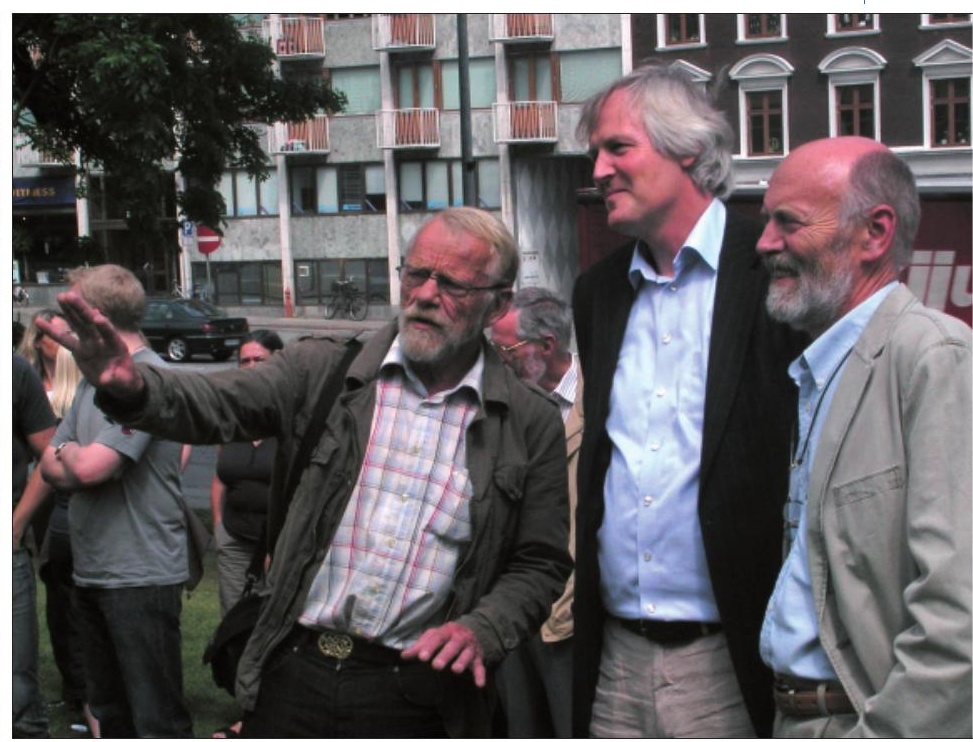

Magnus Krogh Andersen fortceller John Korstgård og Brian Jepsen om skulpturen. (Foto: Ulla V. Hjuler)
Af geolog Ulla V. Hjuler, GeologiskNyt

Mandag d. 18. juni blev de nye bygninger, som Geologisk Institut, Aarhus Universitet, har overtaget, indviet med en reception. Det er det gamle kunstmuseum i Århus, der efter en gennemgribende ombygning er blevet klart til indflytning. Således er de fleste afdelinger af geologi nu samlet ét sted.

Efter at Geologisk Institut i Århus har været spredt ud på op til 7 forskellige lokaliteter på én gang, er der nu ved at være samling på instituttet. Dog ligger Geomorfologi fortsat på Institut for Fysik og Astronomi, og kvartærgeologerne holder til i bygning 120.

\section{Indvielse}

Institutleder John Korstgård, der indledte dagens arrangement, udtrykte også glæde over, at instituttet ikke længere er spredt over så mange bygninger.

Herefter holdt Dekan Erik Meineche Schmidt tale. Han fandt det meget positivt, at Geologisk Institut med din placering nederst i parken er indgangsportal for hele Universitetsparken, fordi geologien er tværfaglig og således bygger på den brede vifte af fag, som naturvidenskab dækker over. Han udtrykte desuden håb om, at geologi måtte opnå større interesse blandt unge mennesker, idet behovet for geologer er stigende.

\section{Gave til Geologisk Institut}

De fleste gæster bemærkede sikkert, at der stod en høj genstand pakket ind i grønt afdækningspresenning foran indgangen: En gave skænket til instituttet. Næste punkt på programmet var netop afsløringen af denne gave skænket af Altinex AS repræsenteret ved Brian Jepsen, der selv har læst hér i År- hus og afsluttede sit studium i begyndelsen af 1980'erne.

Bag ved presenningen gemte der sig en skulptur i rød granit (Helletsbakke brud, Bornholm) på omtrent 3,5 meters højde med navnet "Indsigt" - udformet af kunstneren Magnus Krogh Andersen. Efter således at have fjernet kunsten for at give plads til Geologisk Institut, blev den genindført! En fin afslutning på indvielsen.

Derefter kunne gæsterne besigtige indretningen af instituttets nye bygninger.

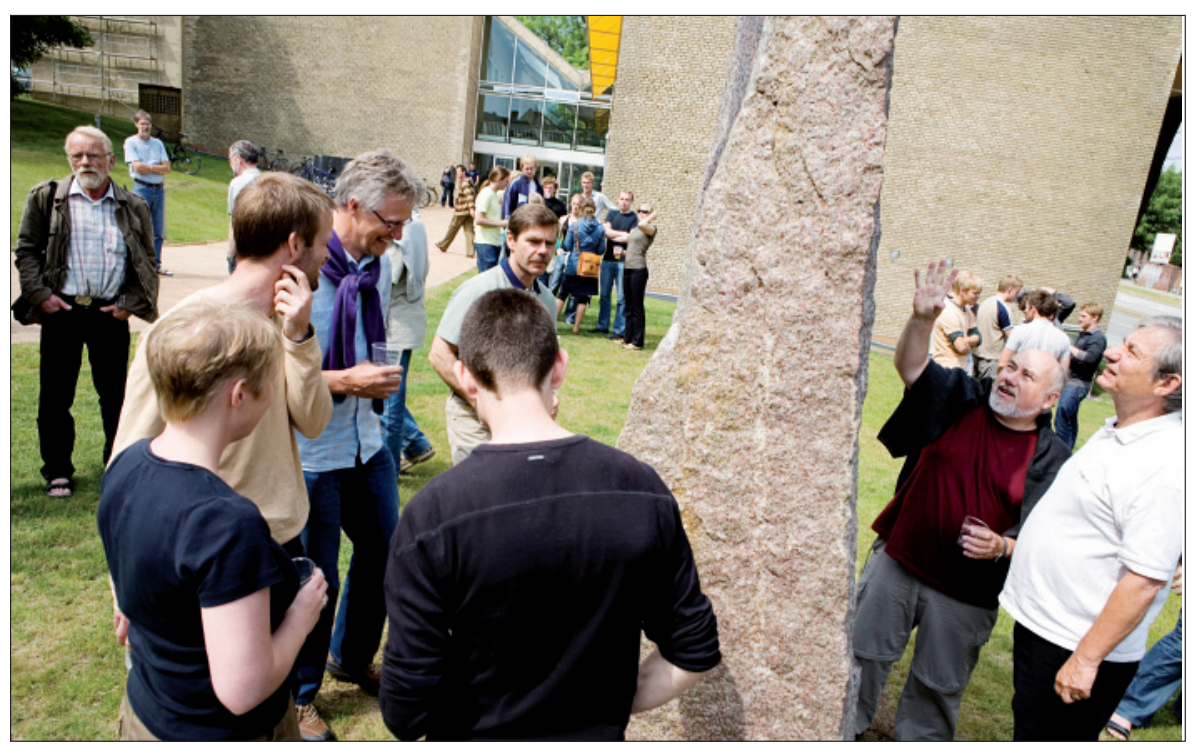

Skulpturen beundres af gaesterne. (Foto: Søren S. Kjeldgaard) 